\title{
Managing social and environmental activities: toward the sustainability of company
}

\author{
Peni Nugraheni ${ }^{1 *}$, Arum Indrasari ${ }^{2}$, Noradiva Hamzah ${ }^{3}$, Ruhanita Maelah ${ }^{4}$ \\ ${ }^{1,2}$ Department of Accounting, Universitas Muhammadiyah Yogyakarta, Yogyakarta, Indonesia \\ ${ }^{3,4}$ School of Accounting, Universiti Kebangsaan Malaysia, Bangi, Malaysia \\ ${ }^{*}$ Corresponding author email: peninugraheni@yahoo.com
}

\section{A R T I C L E I N F O}

Article history:

Available online

Keywords:

Social, environment, reporting,

management, sustainability

DOI:

https://doi.org/10.20885/jaai.vol24.is s2.art6

\section{A B S T R A C T}

Company's contribution to community through social activities and participations in protecting the environment gets more attention from the society. Similarly, the awareness of the company to contribute to the welfare of the community is also increasing. The paper aims to describe the importance of Corporate Social and Environmental Activities (CSEA) and the strategy of the company in managing and reporting CSEA. The sources of the data in this study were the secondary data from the previous literature, annual reports, and sustainability reports of the companies which were analyzed regarding to their implementations of CSEA. Some actions need to be planned by the companies to maximize their contributions to society through CSEA; among others are allocation of specific funds, establishment of specific department or division to manage CSEA, formulation and implementation of CSEA, disclosure and monitoring of CSEA. CSEA and its implementation report can influence the sustainability of company because the stakeholders will have positive appraisal to the company. This study is expected to provide an overview on the management of CSEA as a form of corporate social responsibility in improving the welfare of the community.

\section{Introduction}

The existence of a company will definitely affect the surrounding environment, either directly or indirectly, while the sustainability of the company can be influenced by supports from various stakeholders, including the society around the company. Therefore, how companies put their position in the society is very important. Companies must be able to make a positive contribution to society by managing their business activities well which are reflected in their corporate social activities (Omran \& Ramdhony, 2015).

Corporate Social and Environmental Reporting (CSER) emphasizes on the Corporate Social and Environmental Activities (CSEA) as part of company performance (Ali \& Rizwan, 2013). In general, social activities of a company are often mentioned as Corporate Social Responsibility (CSR). Rosli et al. (2017) state that CSR shows the company's ethical behavior to the community as one of the company's stakeholders while at the same time demonstrating the company's compliance with the government regulations towards the surrounding environment. The statement supports the study of Omran and Ramdhony (2015) which states that CSR shows the role of a company in society as an institution that has ethics, social, and legal responsibility. Some examples of CSER implementation include the use of energy efficiently, equal opportunities for local society to work for the companies, and environmental conservation activities (Haider, 2010).

Several studies have tried to see the extent to which CSEA have been carried out and disclosed by companies. Through the annual report, they identified the quantity and quality of their Corporate Social and Environmental Reporting (CSER) presented (Aribi \& Gao, 2011; Mirfazli, 2008; Trireksani \& Djajadikerta, 2016). Other studies have also tried to examine the factors that influence CSER disclosure in companies, such as company characteristics, corporate governance, and financial ratios (Ali \& Rizwan, 2013; Dienes \& Velte, 2016; Gunawan, 2013). According to Hossain et al. (2017), CSER will depend on the managerial motivation. Therefore, the implementation of CSEA in a company may depend on the motivation of the company to determine how much the company will contribute to the society. Furthermore, there are several motivations for companies to disclose CSEA, including obtaining legitimacy from the community, maintaining the company's reputation, complying with the government regulations, and maintaining the sustainability of the company in the long term (Dobbs \& Staden, 2016; Gunawan, 2015). However, the company's awareness or motivation can influence the extent to which the efforts of the company will be carried out to realize Corporate Social and Environmental (CSE) activities. The previous studies used to analyze the contents of CSR in annual reports to measure the level of CSR disclosure by 
identifying the items of disclosure. However, there are not many papers that discuss how companies manage and carry out their CSR activities. This study attempts to fill that gap by analyzing other aspects of CSEA and CSER.

The study aims to describe the importance of Corporate Social and Environmental Activities (CSEA) by describing several stages or strategies taken by company in conducting CSEA and publishing CSER (Corporate Social and Environmental Reporting). CSEA shows the contribution of company to the welfare of society and environmental conservation. The importance of this study can be seen from several aspects. First, this study tries to describe several company strategies to manage CSEA. Although the companies may publish CSER, the way each company manages and publishes CSEA can be different from one company to another. Stakeholders can assess the extent of the company's strategies in developing its CSEA. Second, the management process of CSEA can at least show a company's efforts in its contribution to the welfare of the surrounding communities. CSEA are implemented as a part of the company activities that must be carried out with prior preparation and planning. Disclosure of the company annual report regarding planning activities and CSEA, and the amount of funds distributed to these activities can indicate whether the company has high concern on these activities or not. However, some previous studies have found that the CSR (CSEA) had positive impacts on company, among others were long-term company sustainability and consumer loyalty building (Dobbs \& Staden, 2016; Gunawan et al., 2020). Therefore, CSEA should be managed as well as possible because the positive impacts will not only be received by the community, but also will influence the sustainability of a company in the stakeholders' viewpoint.

This study will be divided into several sections. The second section discusses the literature reviews related to CSEA and CSER, such as Stakeholder Theory as one of the theories that is often associated with the motivation of companies to implement CSEA, the benefits of CSEA, and the previous studies on CSER. The third section describes the research methodology, and the fourth section discusses some strategies to implement CSEA in a company. The last section is conclusion, impact of the study, as well as the study limitation and suggestions for the future studies.

\section{Literature Review}

One of the indicators of a good performance of a company in conducting business is determined by the role of the management in successful maintenance of the relationships between the company and its stakeholders. Freeman (2004) defines stakeholder as "any group or individual that can affect or be affected by the achievement of a corporation's purpose". Stakeholders include several parties, namely investors, creditors, suppliers, customers, governments, communities, employees, or regulatory bodies. Ali and Rizwan (2013) explain the two branches of Stakeholder Theory based on the previous studies: normative and managerial branches. Normative or ethical branch sees that all stakeholders have equal position to get the information from the company. While from the managerial branch perspective, stakeholders will be considered from their contribution to the company. According to this perspective, all information including CSER will tend to be provided first to the needs of primary stakeholders (who have bigger contribution) such as government or shareholders. Primary stakeholders have important roles in which their contributions will help the sustainability of a company, while secondary stakeholders do not have direct influence to the survival of the company (Ali \& Rizwan, 2013; Polonsky, 1995). Mehedi and Jalaludin (2020) argue that Stakeholder Theory is used to explain the behavior of companies in maintaining good relations with stakeholders, especially those in accordance with corporate interests. Providing financial and non-financial information is a way for companies to establish communication with stakeholders. Meanwhile, Omran and Ramdhony (2015) state that the importance of a company to play an active role in the society, especially in the surrounding environment where the company operates is one of the company's good initiatives to establish a harmonious relationship with its stakeholders.

The existence of a company is not only aiming to get profits for the company itself, but also making positive contributions to the society in economic, social, and environmental aspects (Trireksani \& Djajadikerta, 2016). The contributions of a company in those aspects can be seen from the information provided in CSER. Gray et al. (2001) defines social and environmental disclosure as "comprising information relating to a corporation's activities, aspirations, and public image with regard to environmental, community, employee and consumer issues". Other definition is stated by Hossain et al.(2017) that CSER refers to "any financial or non-financial disclosure made by firms on the social and environmental effects of their business", and remains mostly a voluntary activity. Muslichah (2020) explains that social disclosure is "published information related to human welfare", such as education, economics, and health of the local community, and she also defines environmental disclosure as "a collection of information related to environmental management activities in past, present and future" such as how company preserves the environment.

Ali and Rizwan (2013) state that the scope of social disclosure includes human resources, consumers, human rights, local community involvement, the policies in favor of the community, and compliance with laws and regulations. Meanwhile, environmental performance can be seen in the aspects of efficient use of resources and energy, environmental preservation, as well as treatment of emissions and pollution. According to Ali and Rizwan 
(2013), the contribution to society will have positive impacts on the company, including competitive advantage and increasing company reputation. High public trust in a company will have impact in the long run in terms of increasing profitability. The references also show that companies that are active in the community activities will be more sustainable (Dilling, 2010; Martínez et al., 2016).

Theoretically, a company's motivation in carrying out the activities that have impacts on social life and surrounding environment can be influenced by internal and external factors. The internal factors refer to the influence from internal parties, such as the board of directors, commissioners, and shareholders that encourage the company to be active in the community activities, meanwhile, the external factors come from the encouragement of the parties such as government and society. Dienes and Velte (2016) state that the management of a company should be aware of the necessity of sustainability report for stakeholders to reduce the information asymmetries. The sustainability of a company will be influenced by the trust of the stakeholders toward the company. Martínez et al.(2016) argue that a company will have consistent economic growth if the company is able to keep its activities and has no negative impact on the society, in both social aspect (poverty, hunger) and environmental aspect such as pollution and environmental contamination.

The previous studies have described the implementation of CSER in several countries. Using Stakeholder Theory, Hossain et al. (2017) study the motivation of companies in Bangladesh in disclosing CSER. Based on the findings, they argue that the disclosure conducted by the companies are motivated by self-interest and imagebuilding. Disclosure also aims to reduce the pressure from stakeholders, such as government and international buyers. Dobbs and Staden (2016) find that community and shareholders are the parties that have the biggest influence on the disclosure of CSER in New Zealand companies. They find that the company commitment to CSER is still low because the disclosure is only made to get legitimacy from the stakeholders. Therefore, they suggest the need for a "formalized system" to ensure the accurate and comprehensive disclosure.

Haider (2010) examines the factors that influence CSER in developing countries and argues that company characteristics, general contextual factors, and internal contextual factors can influence CSER disclosure. Haider (2010) also states that the choice of theory to explain CSER disclosure, such as Legitimacy Theory, Stakeholder Theory, and Socio-economic Theory must be adjusted to the characteristics of the socio-economic conditions in which the company is established. Mehedi and Jalaludin (2020) describe the important role of stakeholders in encouraging the implementation of CSR of the companies in developing countries. The focus of companies is usually more on the economic aspect so that interest in CSR is still at a low level. The pressure from the stakeholders then will motivate the companies to engage in CSR activities which are tailored to the characteristics of the company.

Government is one of the stakeholders that can influence the implementation of CSER in companies. By issuing regulation related to the CSR activities, government can "force" companies to do CSR in accordance with the capabilities of each company, but with a predetermined minimum standard. Torugsa et al. (2013) state that companies in Australia are under greater pressure to conduct CSER since the government issued the regulations on limitation of carbon emissions and reducing carbon pollution. Yaya et al. (2018) also state that after the issuance of the regulations on CSR obligations by Indonesian government, CSR disclosures by companies in Indonesia are increasing. CSR disclosure of companies can also be encouraged by giving rewards or recognition from the government or other credible institutions. The rewards will spur the companies to continue improving their CSER performance (Albertini, 2013). Mirfazli(2008) states that reward in the environmental sector is one of the concerns of stakeholders in the disclosure of annual report.

Companies may have different strategies in managing the activities of CSE, depending on the policy of the company and the surrounding environment. According to Kotler and Lee (2005), companies can take several initiatives to support CSE activities. These initiatives are (1) providing funds and resources for social activities, (2) setting a percentage of sales revenue to be used in social activities as a form of corporate commitment, (3) doing campaigns to encourage healthy behavior in order to preserve the environment and community welfare (4) providing direct funds for community activities, (5) inviting partners to support community activities, and (6) conducting business activities that support community welfare and maintain environmental sustainability.

\section{Research Methods}

This study used a descriptive method to describe the strategies of companies in managing CSE activities. Descriptive study is useful to explain common phenomena and relationships between the phenomena investigated. According to Kothari (2004), descriptive research is useful to "portray accurately the characteristics of a particular individual or situation of a group". He further states that the type of study can describe what is happening and analyze it to make a critical evaluation.

The data in this study were secondary data that came from the previous literatures related to CSER disclosure and its impacts, also the motivation of company in publishing CSER. This study used annual reports and sustainability reports of the companies to analyze their implementations of CSER. Twenty annual reports of 
Indonesian companies in environmentally sensitive industries (mining, agriculture and chemical industry) were analyzed to find the forms and contents of CSR information that would be used to describe CSEA and CSER disclosed by the companies. Some previous studies also used descriptive method in explaining CSER such as the studies by Haider (2010) and Martínez et al (2016).

\section{Results and Discussion}

CSER includes the information about the quality and safe products and services, company involvement in community activities, and environmental preservation (Ali \& Rizwan, 2013). The role of manager is very important in encouraging CSEA and CSER to show the contribution of a company for the welfare of the community, especially when the company activities are directly related to natural resource management because it will have a direct impact on people's lives. Some studies discussed the important impacts of CSER, not only on the community, but also on the company itself, such as improving the risk management and long-term performance, maintaining its market position, and creating good relationship with customers, suppliers, and government (Dilling, 2010). When a company can carry out the activities smoothly because of community support, it indicates the sustainability of the company which is a long-term benefit.

The motivation of a company to implement and disclose CSER may be influenced by several factors, including the parties from both internal and external companies. According to Haider (2010), CSER in a region or country will differ depending on the existing environmental conditions. It can even be influenced by social, environmental, and political aspects in that area. Developing countries tend to focus on the issues on child labor, human rights, or women empowerment, while the issues of CSER in developed countries is more related to the quality of products and services and human resources (Haider, 2010; Mehedi \& Jalaludin, 2020). The implementation of CSEA can also depend on the policy of a company regarding the management of CSEA and CSER. Rao and Tilt (2016) state that the characteristics of board of directors have influence on the CSR reporting in Australian companies. The similar result can be found in the study of Naseem et al. (2017) which state that board characteristics have impact on the CSR disclosure in the listed companies at Pakistan stock exchange. CSR can result in the better performance of companies in some aspects, both financial and non-financial performance.

However, the management of CSE activities may differ among companies. The CSE activities will depend on the ability of the companies in managing their organization, human resources, and funding to be directed at the management of CSEA. Company can build some strategies to manage CSEA. Through CSER, the stakeholders can assess the level of company awareness in managing CSEA by identifying the programs or activities conducted by the company. Those programs include:

\section{Allocating Specific Funds for CSEA}

Actually, there are no provisions governing the amount of CSEA funds that must be spent by companies. However, the amount of CSEA funds can show how much the attention of the company on this activity. Companies can allocate CSEA funds each year in the form of nominal figures or a percentage of the income/profits earned in the previous year. The greater the profit generated by the company, the greater the CSEA funds allocated by the company. This is in accordance with the statement of Omran and Ramdhony (2015) that companies can set aside the funds for CSR in the form of a percentage of revenue or provide cash as a contribution to the charity activities. The amount of CSEA funds can be seen in the disclosure of CSER in the company's annual report. Complete CSER disclosure is indicated by details of CSE activities and the amount of funds released. Garcés-Ayerbe et al. (2012) argue that a company with high awareness in developing CSEA will have a special budget for this activity.

Wang et al. (2017) state that the expenditure arising from CSE activities is one of the company's concerns. In general, the expenditure of a company will be considered from the aspects of cost and benefit. For example, companies may have to invest in high costs to use technology for maintaining the environmental sustainability, such as pollution or noise control levels in the industry or waste reduction.

This may be burdensome for certain companies because they are also required to carry out the operational activities efficiently. Therefore, company may consider the amount of money to be distributed in CSE activities in the form of whether revenue percentage or fixed amount regardless the company profit. However, according to Chuang and Huang (2018), those additional expenditures will lead to cost reductions in other activities such as production efficiency or return on initial investment. Those cost reductions will affect the competitive advantage in terms of better company performance.

\section{Establishing a Department or Division that Specifically Manages CSER}

The importance of CSEA encourages companies to establish a division that specifically manages CSE activities. Through this division, the companies can make designs or programs related to social and environmental activities, 
especially those that are priorities at that time. Companies that are active in CSR activities usually have their own department that specifically manages these programs (Garcés-Ayerbe et al., 2012).

The importance of making a CSE program in the initial step is because it is expected to achieve maximum contribution results. It is not only giving social assistance but there is no continuation program. Therefore, the company can conduct a survey first to see the situation and determines the program priorities as well as the steps that must be taken. Some CSE programs may not be completed within one year because they need to be implemented in several years. Thus, the benefits of the CSE programs will not only be received in the short term, but also in the long term, where the community can get the benefits from the company's CSE programs.

The function of CSE department is not only to create the programs related to social and environmental activities but also to integrate the activities carried out both by the company and by the stakeholders. Wang et al.(2017) argue that company needs to integrate its activities with those of the stakeholders such as the suppliers and other business partners to jointly carry out the activities that lead to sustainability. It means that internal and external parties must have the same steps in achieving the goals that have been set. Thus, the department can consider what strategies will be used to be able to collaborate with the activities of the stakeholders to realize the effective CSE programs and achieve maximum contribution. A CSE program that can be implemented in a measured and efficient manner, accompanied by sufficient funding, will be able to increase the company's competitiveness and sustainability (Chuang \& Huang, 2018).

\section{Formulation of CSE Activities or Programs}

A program will work effectively if it is planned carefully. Companies should not only plan the activities related to operational activities such as the production and marketing of goods and services, but also the implementation of CSEA which requires planning in advance. This aims to learn what kind of programs needed by the surrounding community and at the same time to determine the program priority that will be implemented first.

The program ideally also has the required budget attached which is according to the company budget policy on CSEA and CSER. The bigger the budget provided, the more flexible CSER or CSR department in planning the programs to be carried out. According to Haider (2010), CSE programs conducted by a company may be influenced by several factors such as corporate characteristics (size, ownership type), general contextual factors (culture and religion, country of origin, economic development level, politics and government), and internal contextual factors (reporting process and attitudes of internal people). Hossain et al.(2017) interviewed the manager of a Bangladesh firm and found that social obligation such as poverty alleviation with the community involvement was the activity in accordance with Bangladesh culture and got prioritized attention from the company. Djajadikerta and Trireksani (2012) find that community and human resources are the issues that have been most disclosed by the companies in Indonesia, while social and environmental aspects have low disclosure. They argue that companies focus more on the employee welfare and community to get recognition for their social behavior.

\section{Implementation of CSE Programs}

Apart from making plans, division or department of CSR is also responsible for implementing CSR programs that have been planned. The programs are the results of surveys on social and environmental conditions to analyze the community needs. Thus, it is expected that the program implemented can indeed contribute to community welfare improvement and environmental sustainability. Some examples of CSE activities include:

a. Social aspects, including opportunities for local society to become company employees, scholarships provision from elementary school to university level, donations, training to improve certain skills, women empowerment, and capital assistance for business entrepreneurship

b. Environmental aspects, which include maintaining pollution and noise level limits, keeping production waste from polluting the environment, and planting trees for greening.

According to Djajadikerta and Trireksani (2012), the concern of CSE activities is fulfilling the needs of stakeholders, especially employees and the community, to get their recognition that the company have contribution to the society. Although these activities require a lot of budget which reduces the company funds, a good relationship between the company and the community will be able to support the sustainability of the company's activities in the long term.

\section{Disclosure of CSE Activities}

The CSE programs conducted by a company then can be disclosed or reported to the stakeholders. Ali and Rizwan (2013) state that CSER disclosure can be done through various media, such as annual reports, websites, and standalone reports. In general, the disclosure of CSE activities is presented in the company's annual report as information material for stakeholders who want to know the company's performance. However, some companies present their 
own CSER in a report that is often called a sustainability report. According to Trireksani and Djajadikerta (2016), the area of sustainability report includes the aspects of environmental disclosure. It aims to provide more detailed and comprehensive information on CSE activities. It is expected that with this separate reporting, stakeholders can get more adequate information about the company's activities.

The use of a company website can also be a medium to provide the information about company activities to stakeholders. Company uses website to provide information because it can be more easily accessed by the stakeholders despite different geographic areas. According to Djajadikerta and Trireksani (2012), public document and media are a communication tool of a company to provide the information about the company activities.

The information in the annual report can be presented in the form of qualitative or quantitative description, or both (Hackston \& Milne, 1996; Raar, 2002). The qualitative report shows a complete and detailed explanation of the CSE activities carried out by a company. A complete explanation can be indicated from the number of words, sentences, paragraphs, pages, and images or photos included, while a quantitative reports contains the nominal value of funds disbursed to carry out CSR activities (Hackston \& Milne, 1996; Nugraheni \& Anuar, 2014). The combined use of qualitative and quantitative methods means that company can describe the CSE activities in detail explanation accompanied with the amount of funds used. Raar (2002) argue that the third method is more meaningful to help the stakeholders in making economic decision because the information is presented completely both in qualitative and monetary terms.

According to Dobbs and Staden (2016), high quality information provided by a company will help stakeholders to make decision like buying the products (customers), providing the raw materials (suppliers), investing in certain companies (investors) and determining the regulation related to CSER disclosure (regulator). Thus, the stakeholders can find out about the company's CSE activities and assess the level of the company's concern of the surrounding environment.

Chapple and Moon (2005) state that CSR reports are a common phenomenon in European countries. On the contrary, the number of Asian countries which compose CSR reports is still low despite the potential growth in Asia which is driven by the large number of multinational companies. Ali and Rizwan (2013) analyzed the data from GRI in 2010 which stated that the most of sustainability reports were published by European countries reaching 45\%, while the number of Asian countries publishing the reports reached 20\%, and Africa was the countries with the least number in producing sustainability reports with the percentage of $3 \%$.

\section{Monitoring of CSEA and CSER}

Monitoring is the next step to evaluate the implementation of CSEA and CSER. Monitoring will encourage the managers to maintain and improve the CSE programs in order to perform the company's contribution to the community (Fauzi et al., 2010). Monitoring can be done by evaluating whether the program has been implemented in accordance with the plan and budget that has been determined.

According to Chapple and Moon (2005), the implementation of CSE programs can be evaluated from some indicators, namely guidance, processes, employees, budget, and disclosure of CSER. Therefore, management can evaluate some aspects, including: First, the effectiveness of the program being carried out, whether it is running well or not; second, the beneficiaries of the program, whether or not they are people in need; and third, the output produced, whether or not it is in accordance with the objectives setting. Management can ask the inputs from CSR department or the parties who implemented the program, related to the supporting and inhibiting factors, which are experienced from planning to program implementation. The community as the beneficiaries of the program can be asked for their opinions regarding the effectiveness of the program.

Monitoring can also be used to evaluate the programs and approaches that have been implemented by the company. Companies must be able to socialize CSE programs so that they are easily accepted and understood by the community (Muslichah, 2020). According to Colleoni (2013), monitoring will give information to the company about the stakeholders' reaction on the CSR programs. Monitoring activity is useful as the basis for the improvement of the preparation and implementation of CSE programs in the following period.

\section{Conclusion}

Corporate Social and Environmental Reporting (CSER) is a form of company concern for the surrounding community in the form of activity programs aimed at improving the community welfare and preserving the environment. The government has obliged companies to carry out CSR activities. However, the variety of the activities regardless the amount of funds distributed for these activities depends on the company policy. A company may consider the amount of money distributed to CSE activities because it will lead to larger company expenses. Therefore, the considerations on the costs and benefits often determine the decision about the extent of the company contribution to these activities.

The management of a company has an important role in encouraging the implementation of CSEA and CSER through predetermined policies. The company's contribution in CSE activities is able to give a positive impact 
that is not only received by the community but also by the company itself. It will indirectly create a harmonious relationship between the company and the community. Therefore, CSR should be part of a company's activities that must be planned and prepared in advance so that it will provide maximum results. Some actions need to be planned by companies to maximize their contributions to society through CSE activities, among others are allocating specific funds for CSEA, establishing specific department of division to manage CSE activities, formulating CSE programs, implementing CSE programs, disclosing CSE activities, and monitoring CSE activities.

Those actions may vary in the implementation between different companies. The extent to which a company implements the strategy can be influenced by many factors, including capability and management policies. This study is expected to give contribution in the CSER literature and provide insight about the management of CSE activities and CSE reporting in a company. Moreover, some strategies explained in this paper are expected to give descriptions on how a company can manage its CSEA by implementing certain strategies that affect the quantity and quality levels of CSEA and CSER.

This study has limitation related to the descriptive method used in this study. The explanation about the analysis on the strategies carried out by companies in managing and reporting CSEA is described generally. Meanwhile, the policy of each company and the policy of each country regarding CSR or CSER may differ, so the implementation between companies may also be different. In addition, the use of primary data such as interviews with the company management can provide more justification about the company policies in managing CSEA. However, this paper is to assist the stakeholders in identifying what strategies taken by a company related to the availability of CSER information in the annual report.

\section{Acknowledgement}

This article is a part of research funded by internal research grant of Institute for Research, Publication, and Community Service (LP3M), Universitas Muhammadiyah Yogyakarta, Indonesia.

\section{References}

Albertini, E. (2013). Does environmental management improve financial performance? A meta-analytical review. Organization and Environment, 26(4), 431-457. https://doi.org/10.1177/1086026613510301

Ali, W., \& Rizwan, M. (2013). Factors influencing corporate social and environmental disclosure (CSED) practices in the developing countries: an institutional theoretical perspective. International Journal of Asian Social Science, 3(3), 590-609.

Aribi, Z. A., \& Gao, S. (2011). Narrative disclosure of corporate social responsibility in Islamic financial institutions. Managerial Auditing Jounal, 27(2), 199-222. https://doi.org/10.1108/02686901211189862

Chapple, W., \& Moon, J. (2005). Corporate social responsibility (CSR) in Asia: A seven-country study of CSR web site reporting. Business and Society, 44(4), 415-441. https://doi.org/10.1177/0007650305281658

Chuang, S.-P., \& Huang, S.-J. (2018). The effect of environmental corporate social responsibility on environmental performance and business competitiveness: The mediation of green information technology capital. Journal of Business Ethics, 150(3), 991-1009. https://doi.org/10.1007/s10551-016-3167-x

Colleoni, E. (2013). CSR communication strategies for organizational legitimacy in social media. Corporate Communications: An International Journal, 18(2), 228-248. https://doi.org/10.1108/13563281311319508

Dienes, D., \& Velte, P. (2016). The impact of supervisory board composition on CSR reporting. Evidence from the German two-tier system. Sustainability, 8(64), 1-20. https://doi.org/10.3390/su8010063

Dilling, P. F. A. (2010). Sustainability reporting in a global context: What are the characteristics of corporations that provide high quality sustainability reports an empirical analysis. International Business \& Economic Research Journal, 9(1), 19-30.

Djajadikerta, H. G., \& Trireksani, T. (2012). Corporate social and environmental disclosure by Indonesian listed companies on their corporate web sites. Journal of Applied Accounting, 13(1), 21-36. https://doi.org/10.1108/09675421211231899

Dobbs, S., \& Staden, C. Van. (2016). Motivations for corporate social and environmental reporting : New Zealand evidence. Sustainability Accounting, Management and Policy Journal, 7(3), 449-472. https://doi.org/10.1108/SAMPJ-08-2015-0070

Fauzi, H., Svensson, G., \& Rahman, A. A. (2010). "Triple bottom line" as "Sustainable corporate performance": A proposition for the future. Sustainability, 2(5), 1345-1360. https://doi.org/10.3390/su2051345 
Freeman, R. E. (2004). The stakeholder approach revisited. Zeitschrift Für Wirtschafts- Und Unternehmensethik, 5(3), 228-254.

Garcés-Ayerbe, C., Rivera-Torres, P., \& Murillo-Luna, J. L. (2012). Stakeholder pressure and environmental proactivity : Moderating effect of competitive advantage expectations. Management Decision, 50(2), 189206. https://doi.org/10.1108/00251741211203524

Gray, R., Javad, M., Power, D. M., \& Sinclair, C. D. (2001). Social and environmental disclosure and corporate characteristics: A research note and extension. Journal of Business Finance \& Accounting, 28(3), 327-356. https://doi.org/10.1111/1468-5957.00376

Gunawan, J. (2013). Determinant factors of corporate social disclosures in Indonesia. Issues in Social and Environmental Accounting, 7(2), 113-134.

Gunawan, J. (2015). Corporate social disclosures in Indonesia: stakeholders' influence and motivation. Social Responsibility Journal, 11(3), 535-552. https://doi.org/10.1108/SRJ-04-2014-0048

Gunawan, S., Budiarsi, S. Y., \& Hartini, S. (2020). Authenticity as a corporate social responsibility platform for building customer loyalty. Cogent Business \& Management, 7(1), 1-18. https://doi.org/10.1080/23311975.2020.1775023

Hackston, D., \& Milne, M. J. (1996). Some determinants of social and environmental disclosures in New Zealand companies. Accounting, Auditing and Accountability Journal, 9(1), 77-108.

Haider, M. B. (2010). An overview of corporate social and environmental reporting (CSER) in developing countries. Issues in Social and Environmental Accounting, 4(1), 3-17.

Hossain, M. M., Momin, M. A., Rowe, A. L., \& Quaddus, M. (2017). Corporate social and environmental reporting practices: A case of listed companies in Bangladesh. Sustainability Accounting, Management and Policy Journal, 8(2), 138-165.

Kothari, C. (2004). Research Methodology: Methods and Techniques (2nd ed.). New Age International.

Kotler, P., \& Lee, N. (2005). Corporate Social Responsibility: Doing the Most Good for Your Company and Your Cause. Welly.

Martínez, J. B., Fernández, M. L., Miguel, P., \& Fernández, R. (2016). Corporate social responsibility : Evolution through institutional and stakeholder perspectives. European Journal of Management and Business Economics, 25(1), 8-14.

Mehedi, S., \& Jalaludin, D. (2020). Application of theories in CSR research focusing study context and corporate attributes. International Journal of Ethics and Systems, 36(3), 305-324. https://doi.org/10.1108/IJOES-092019-0146

Mirfazli, E. (2008). Corporate social responsibility ( CSR ) information disclosure by annual reports of public companies listed at Indonesia Stock Exchange. International Journal of Islamic and Middle Eastern Finance and Management, 1(4), 275-284. https://doi.org/10.1108/17538390810919592

Muslichah. (2020). The effect of environmental, social disclosure, and financial performance on firm value. Jurnal Akuntansi \& Auditing Indonesia, 24(1), 22-32.

Naseem, M. A., Riaz, S., Rehman, R. U., Ikram, A., \& Malik, F. (2017). Impact of board characteristics on corporate social responsibility disclosure. Journal of Applied Business Research, 33(4), 801-810. https://doi.org/10.19030/jabr.v33i4.10001

Nugraheni, P., \& Anuar, H. A. (2014). Implications of Shariah on the voluntary disclosure of Indonesian listed companies. Journal of Financial Reporting and Accounting, 12(1), 77-98. https://doi.org/10.1108/JFRA11-2011-0018

Omran, M. A., \& Ramdhony, D. (2015). Theoretical perspectives on corporate social responsibility disclosure: A critical review. International Journal of Accounting and Financial Reporting, 5(2), 38-55. https://doi.org/10.5296/ijafr.v5i2.8035

Polonsky, M. (1995). A stakeholder theory approach to designing environmental marketing strategy. Journal of Business \& Industrial Marketing, 103), 29-46.

Raar, J. (2002). Environmental initiatives : Towards triple-bottom line reporting. Corporate Communications: An International Journal, 7(3), 169-183. https://doi.org/10.1108/13563280210436781 
Rao, K., \& Tilt, C. (2016). Board diversity and CSR reporting: an Australian study. Meditari Accountancy Reserach, 24(2), 182-210.

Rosli, M. H., Said, J., \& Fauzi, N. A. (2017). A brief survey of corporate social responsibility in Malaysia. Selangor Business Review, 2(1), 10-19.

Torugsa, N. A., O'Donohue, W., \& Hecker, R. (2013). Proactive CSR: An empirical analysis of the role of its economic, social and environmental dimensions on the association between capabilities and performance. Journal of Business Ethics, 115(2), 383-402.

Trireksani, T., \& Djajadikerta, H. G. (2016). Corporate governance and environmental disclosure in the Indonesian mining industry. Journal of Applied Accounting and Research, 10(1), 21-36.

Wang, Q., Wang, Z., Zhang, S., \& Zhao, X. (2017). External and Internal Pressures on Corporate Environmental Responsibility. 1th International Conference on Operations and Supply Chain Management, 1-8.

Yaya, R., Wibowo, S. A., Ulfaturrahmah, \& Jalaludin, D. (2018). Environmental disclosure practices after mandatory disclosure policy in Indonesia. Journal of Business and Retail Management Research, 12(4), 88-100. 